\title{
名古屋市堀川の水質に与える松重閘門水域部の ヘドロと中川運河の導水の影響に関する研究
}

\author{
THE EFFECTS OF SLUDGE AT THE WATER AREA FRONT OF MATSUSHIGE \\ LOCKGATE AND INFLOW DISCHARGE FROM NAKAGAWA CANAL \\ ON THE WATER QUALITY OF HORI RIVER
}

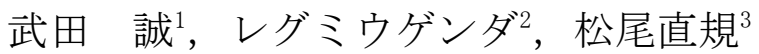 \\ Makoto TAKEDA, Ugendra REGMI and Naoki MATSUO \\ 1 正会員 博士（工学） 中部大学教授 工学部都市建設工学科（テ487-8501 愛知県春日井市松本町1200） \\ 2 正会員 博士 (工学) 中部大学研究生 工学部都市建設工学科（广487-8501 愛知県春日井市松本町1200) \\ 3 フェロー 工学博士 中部大学教授 工学部都市建設工学科（广487-8501 愛知県春日井市松本町1200)
}

This paper treats the water quality problem on Hori river, Nagoya, Japan. Matsushige Lock Gate area is a big water area, situated at the middle part of the Hori River. This area is a place where the maximum sludge has been deposited and still during tidal behaviors, this sludge may play a pivotal role to change the water quality. Moreover, the transmitted water form Nakagawa canal has also made the water quality changed at Hori River. Therefore, water quality observations were done at Matsushige and Sanno Bridge, which are up and down streams of this Lock Gate area. From observation results, the inflow discharge from Nakagawa canal has an impact on the water quality of Hori River. Additionally, ADCP is carried out to find the distributions of water velocity along the longitudinal profile of Hori River. Finally, an effective timing of inflow discharge from Nakagawa canal is examined considering tidal change.

Key Words: Water quality, Hori River, Sludge, Nakagawa Canal, Inflow discharge, ADCP

\section{1. はじめに}

日本の都市河川は，1970年代の高度経済成長期の無秩 序的な污水流入によって水質悪化，へドロ堆積により， 水環境も劣悪となった. その後, 下水道整備やへドロの 浚渫が進み, 当時に比べれば水環境は改善しているが, 十分な状況とは言えない. 図-1に示す名古屋市堀川では 納屋橋付近にオープンカフェが並ぶなど市民に親しまれ ているが，水環境に関する課題も多い，堀川には河口か ら7.5kmに中川運河との合流域である松重閘門があり，そ の前には水域（松重閘門水域部）が存在する. 堀川は, 浮遊物が上流と松重閘門水域部を行き来し長期間堀川を 浮遊する特徵を有しており，松重閘門水域部には大量の ヘドロが堆積している ${ }^{122)}$. 堀川の水環境改善を目指して, 武田らは，現地観測を用いた水質変化の状況を明らかに し, 数值解析により冬季の堀川のDO変化を示し, 中川運 河からの導水の影響が大きいことを示した ${ }^{344)}$ 。また，冨 永ら5は，松重閘門水域部の流れの観測を実施し，ワンド 部特有の渦構造を明らかにしている.

本研究では，まず，「松重閘門水域部に堆積している

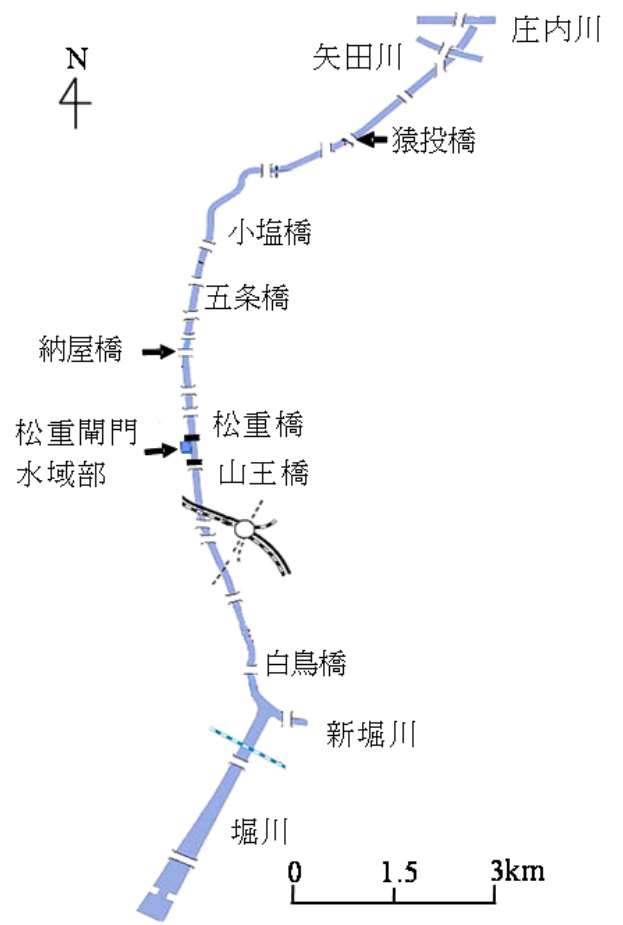

名古屋港

図-1＼cjkstart堀川の概況 


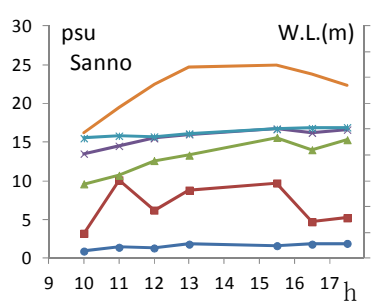

a) $9 / 6$ 小潮 導水なし
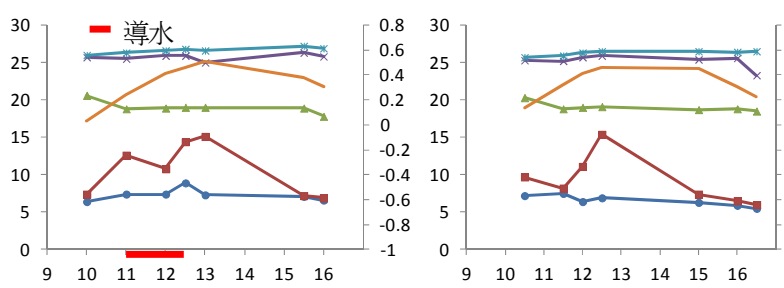

b) $11 / 4$ 小潮 導水あり
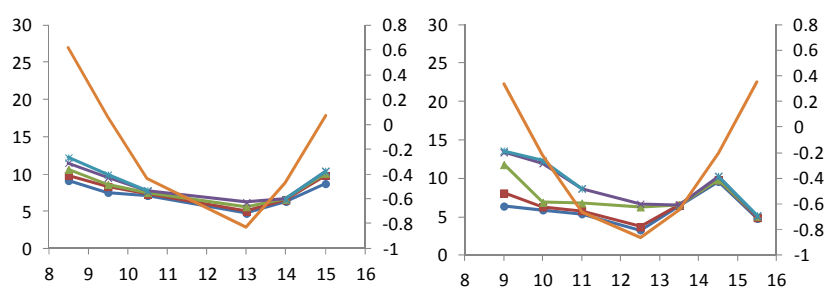

c) 11/26 大潮 導水なし
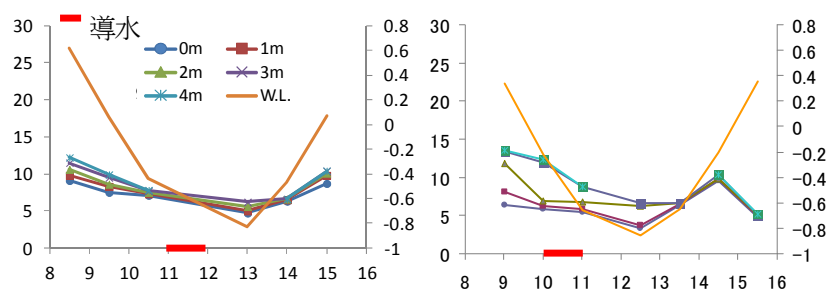

d) 9/28 大潮 導水あり

\section{図-2 塩分}

ヘドロの巻き上げやへドロからの溶出および消費の影響 を受けて，上げ潮時に水域部より上流側の水質が変化し， 下げ潮時には水域部より下流側の水質が変化する」とい う仮説を立て，松重閘門水域部を挟む二つの橋（松重橋 と山王橋）で水質の現地観測を行い，想定した水質変化 のメカニズムの有無を明らかにした．つぎに，堀川の縦 断方向（白鳥橋から小塩橋）のADCP観測により，中川運 河からの導水の影響を明らかにした，最後に，堀川上流 域の水質改善に効果が期待される中川運河からの導水の タイミングについて検討を行った。

\section{2. 松重閘門水域部を挟む二つの橋での現地観測}

松重閘門水域部のへドロ堆積が堀川の水質に与える影 響を評価するため，松重閘門水域部を挟む二つの橋（上 流: 松重橋, 下流: 山王橋) の水面から $0.5 \mathrm{~m}$ (0mと表示), $1 \mathrm{~m}, 2 \mathrm{~m}, 3 \mathrm{~m}, 4 \mathrm{~m}$ において, 多項目水質計 (東覀DKK社 製 WQC-24, 項目項目：水深，塩分，水温，濁度，DO，

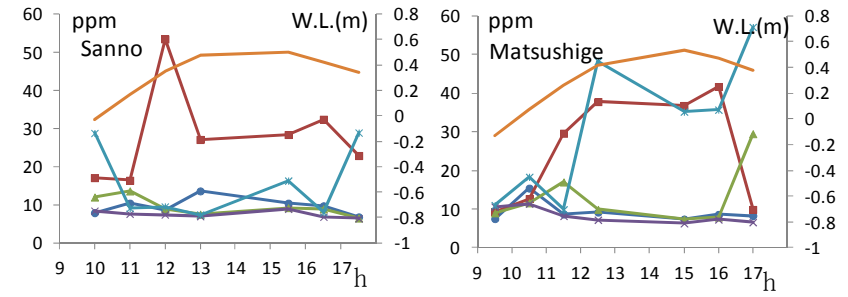

a) $9 / 6$ 小潮 導水なし

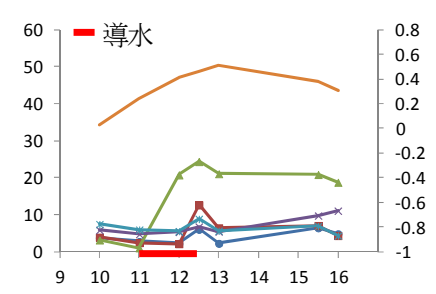

b) $11 / 4$ 小潮 導水あり
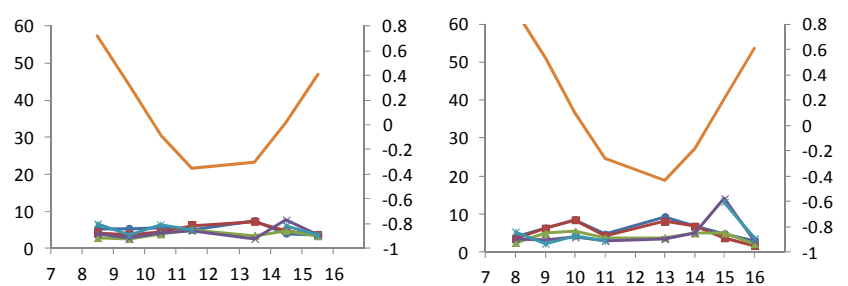

c) $11 / 26$ 大潮 導水なし
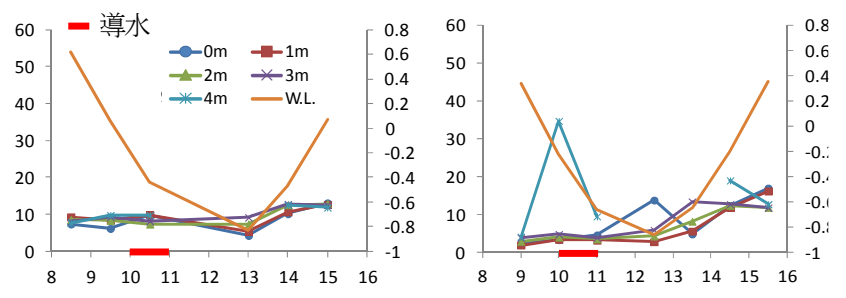

d) $9 / 28$ 大潮導水あり

\section{図-3 濁度}

$\mathrm{PH}$ ，クロロフィルa，ORP）を用いた観測を実施した．観 測日は2011年9月6日（小潮），9月28日（大潮），11月4 日（小潮），11月26日（大潮）であり，9月28日と 11 月 4 日には，中川運河からの導水があった。

水質の時間変化を図-2～図-6に示す．例えば，上げ潮 時に上流の松重橋が下流の山王橋よりDO值が低くなっ ていれば，これはその間にある松重閘門水域部のへドロ の水質に与える負の影響と考えられる. まず，図-2の塩 分の状況から，それぞれに塩分差（成層）がみられ，大 潮時よりも小潮時の方がその差が大きいことが示されて おり，大潮時の中川運河からの導水後では鉛直混合が生 じている．また，図-3の濁度では，松重橋と山王橋の中 間層では同様の值を示している. 小潮時には密度成層が 現れ，密度境界の深さ（9月6日では水面下 $1 \mathrm{~m}, 11$ 月4日で は水面下 $2 \mathrm{~m}$ ）で濁度が高く，9月6日の底層では山王橋よ り松重橋の值が高い. また，特に9月28日には導水後高い 濁度が観測されている．図-4のクロロフィルaでは，松重 橋と山王橋の中間層は同様の值を示している. 9月6日の 


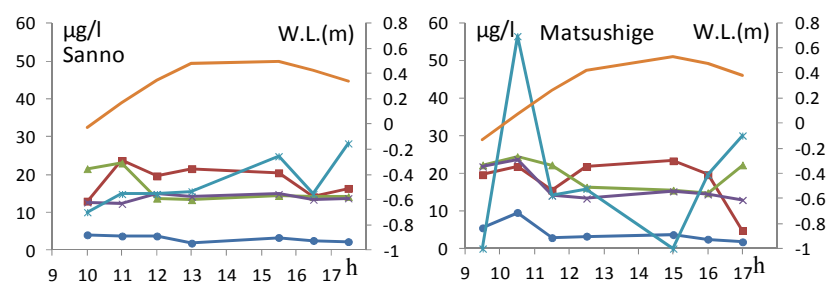
a) $9 / 6$ 小潮 導水なし
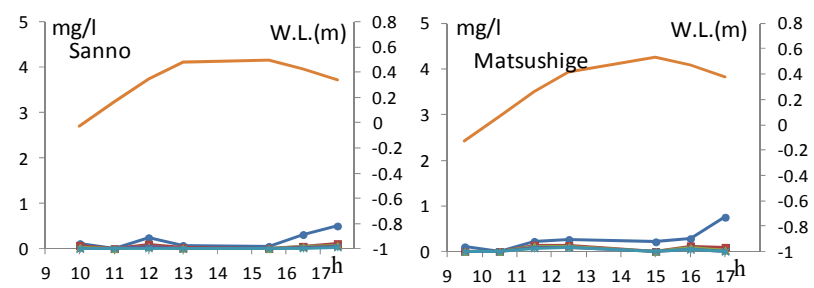

a) $9 / 6$ 小潮 導水なし

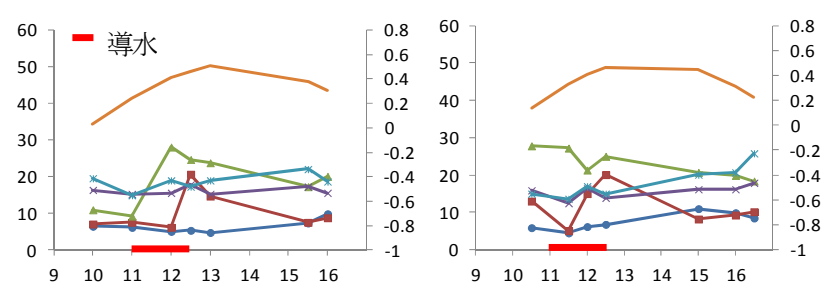

b) $11 / 4$ 小潮 導水あり

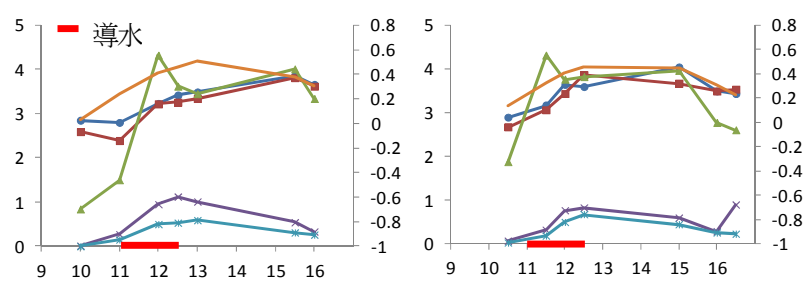

b)11/4 小潮 導水あり

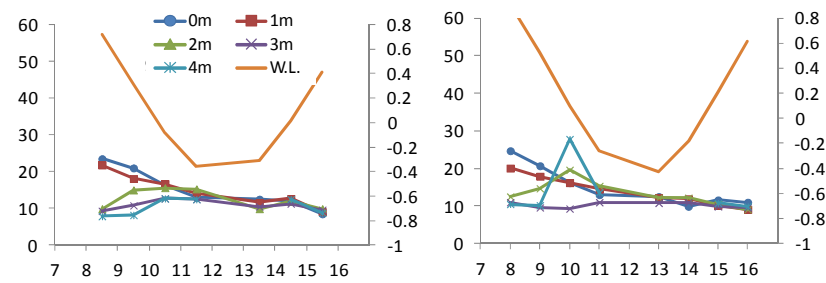

c) $11 / 26$ 大潮 導水なし

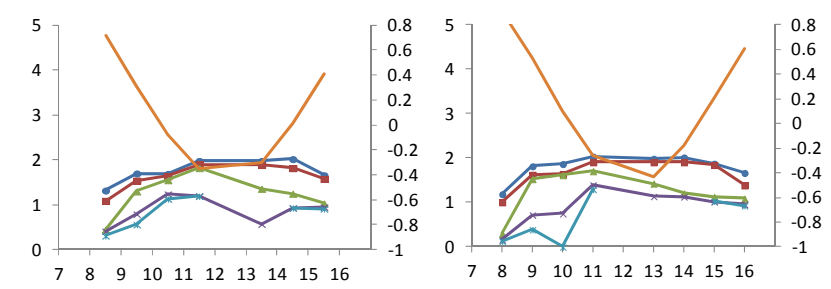

c)11/26 大潮 導水なし

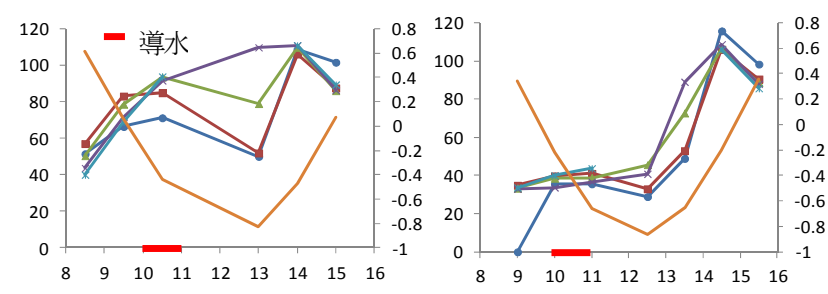

d) 9/28 大潮 導水あり

図-4 クロロフィルa

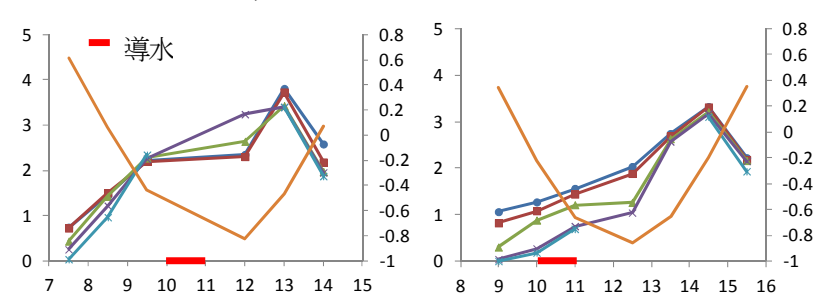

d)9/28 大潮 導水あり

図-5 DO

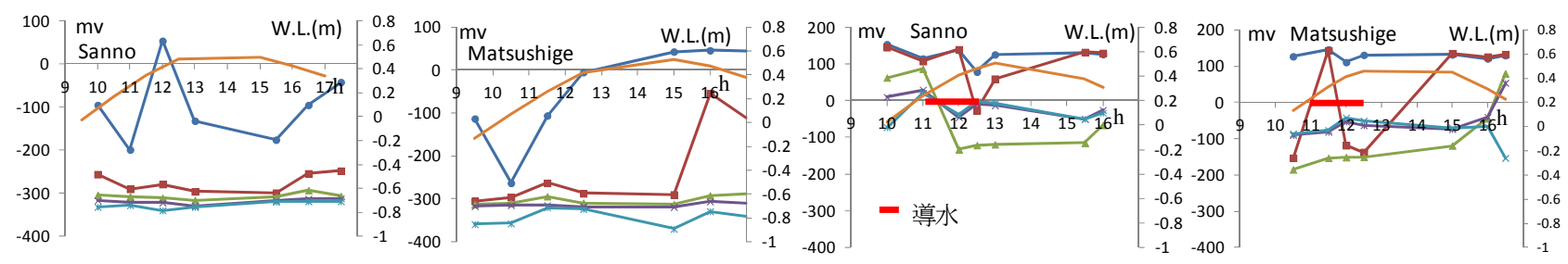

a) 9/6 小潮 導水なし

b)11/4 小潮 導水あり

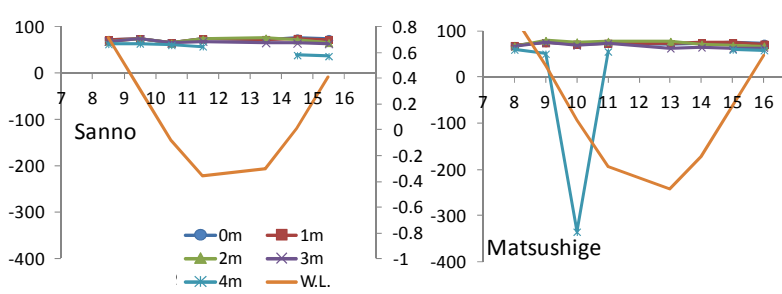

c)11/26 大潮 導水なし

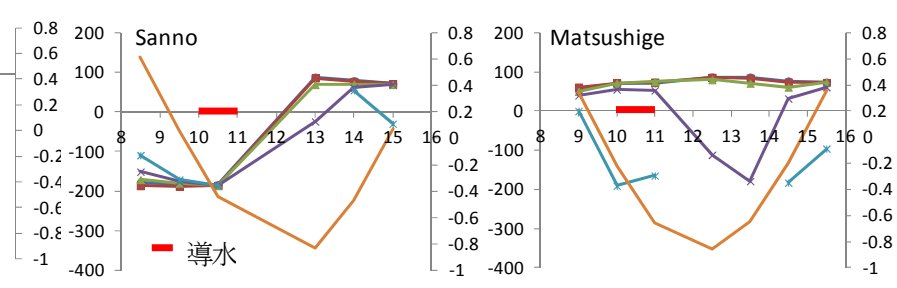

d)9/28 大潮＼cjkstart導水あり

図-6 ORP 
南北方向流速（プラス (赤色) が北方流速, マイナス (紫色) が南方流速)
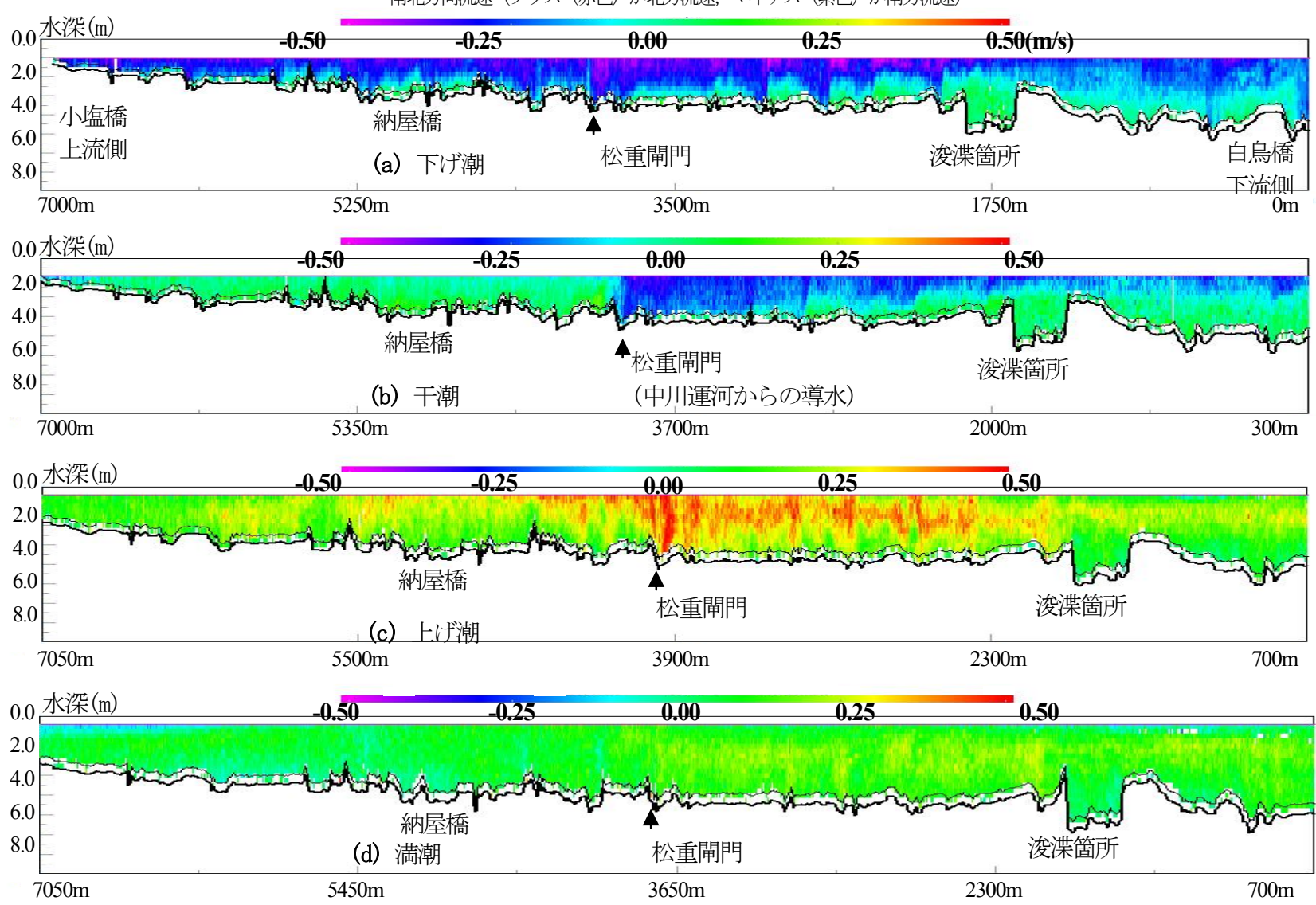

横軸は堀川中心における距離（左が上流，右が下流）, 観測開始場所がゼロ

\section{図-7 縱断方向の流速分布（堀川の中心線}

底層では松重橋のクロロフィルa值が山王橋より高く なっており，これは濁度と同様の傾向である．植物プラ ンクトン（その指標となるクロロフィルa）に対するへド ロの影響として栄養塩の供給があるが，短期的および局 所的には小さいものと考えられる。また，9月28日の中川 運河からの導水後には極めて高いクロロフィルa值が観 測されている．下げ潮時に導水していることから，先に 山王橋で高い值となり，上げ潮に移行した後でその影響 が松重橋に及んだと考えられる．このことから，植物プ ランクトンが増殖する時期の導水の影響は，堀川内で顕 著であることが示された，さらに，図-5のDOについて， 導水の無い(a)と(c)をみると，松重橋と山王橋の計測結果 に大きな差は生じていない.このことから，潮汐流に伴 う松重閘門水域部のへドロが水質変化に与える影響は小 さいものと推察される. 図-5の(b)と(d)には中川運河から の導水の影響が表れている．小潮である(b)の結果は，導 水後に深さ $2 \mathrm{~m} の \mathrm{DO}$ 值が高くなっているのに対して, 底層 はそれほど大きなDO值の増加がみられない，これは，成 層が発達していたため，流入水が密度の大きい底層の上 を流れ，底層に影響を与えなかったと考えられる. 一方， 大潮の場合には，導水後に鉛直混合が生じDO值も高く鈆 直一様となっている. 9月28日の大潮時の観測終了時に松
赤色が遡上する流れ，青色が流下する流れ）

重橋から約 $2.4 \mathrm{~km}$ 上流の五条橋のDOを計測し，2.1mg/l〜 $2.2 \mathrm{mg} /$ という松重橋と同じ值を得た。これは，導水の影 響が上流域にまで広がっていることを示している。これ らの結果から，潮汐流に伴う松重閘門水域部に存在する ヘドロの水質への影響よりも，中川運河からの導水の堀 川水質に与える影響がはるかに大きいことが示された. また，図-6にはORPの観測結果を示している. ORPは酸 化還元電位であり，酸素が不足している底層において底 泥の化学反応により負值となることが知られている. 図 -6を見れば, 11月4日の導水後の山王橋深さ2m地点におい て負值となっている。これは，上げ潮にも関わらず，導 水により松重閘門水域部の底層の水塊が深さ $2 \mathrm{~m}$ の層を流 下しているものと推察される.

\section{3. 堀川の縱断方向のADCP観測}

2011年7月26日（小潮）に白鳥橋から小塩橋までの断面 中心部における堀川縦断方向のADCP流速観測を実施し た. 得られた結果を図-7に示す。計測開始地点と測定ラ インに多少のズレが生じていたので図-7に目印となる場 所を明記している。本図から，弱流れ（あるいは停滞 する流れ）となる干潮時（図-7(b)）には，松重閘門から 
下流へ向かう強い流速が生じている. また，上げ潮時 (図 -7(c)）では，強い流れが表層よりも下の中間層で生じて おり，松重閘門よりも上流で流速が弱まっている。これ らは，松重閘門からの導水の影響と考えられる.

中川運河の水質は，夏期において，植物プランクトン が増殖するためDOも高い值となっている．DO值の高い 水の流入は，溶存酸素の乏しい堀川にとっては良好な水 といえる. しかし，図-7のように，流入した水が上流一 向かわずに下流に流れるようでは，上流の納屋橋に導水 が届かず，納屋橋周辺の水質改善が期待できない，した がって, 潮汐に伴う効果的な導水のタイミングの検討が つぎの課題である.

\section{4. 中流域への導水輸送に関するモデル解析}

中川運河からの導水は高い溶存酸素の水となる場合が あり，この水塊を堀川上流域に移流できれば水質改善が 期待できる. ただし，そのためには潮汐に伴う導水の効 果的なタイミングを検討する必要がある。そこで，まず， 領域平均された現象として問題をとらえ，図-8を参考に 図-9の離散化された支配方程式を行列式に置き換えて, 時間発展させながら流動解析を行った．また，得られた 流量および領域の体積 $(\mathrm{V})$ を用いて差分法により移流方 程式を解き，中川運河からの導水などそれぞれの水域に 占める割合（1が最大值）を求めた。ここで，F(i)upは風 上性を考慮している．紙面の都合上，図-9には領域1の移 流方程式の夕を記し，用いた変数は図-8および図-9で説 明する．なお，導水の輸送の解析におけるiは1〜4まで変 化し，1は河口の水，2は初期に滞在する水，3はQinによっ て流入する中川運河の水，4は上流加の流入水とする. なお，海側境界条件となる潮位は大潮を想定し振幅 $1 \mathrm{~m}$, 周期12時間とした．また，上流からは庄内川からの導水
猿投 $(13.6 \mathrm{~km})$ 松重 $(7.59 \mathrm{~km})$ 山王(7.29km) 河口

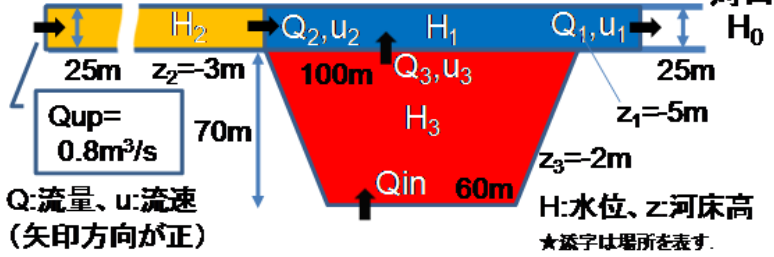

図-8 モデルの概念図（青 : 領域 1，黄 : 領域 2, 赤 : 領域 3)

流れの解析

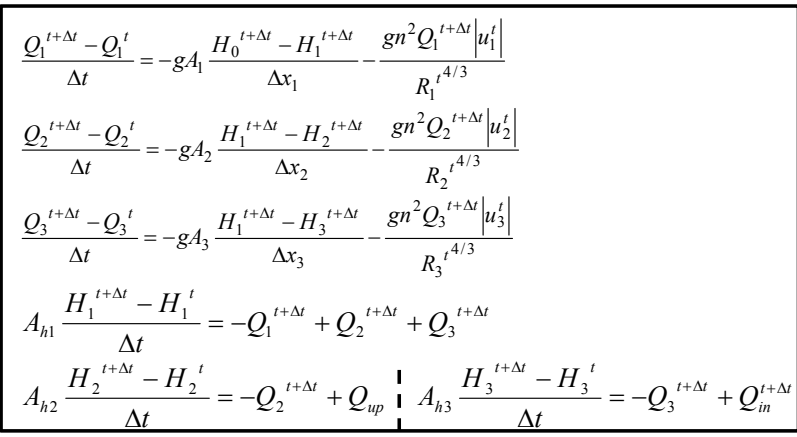

導水の輸送の解析 (一部, 領域1の移流方程式)

$$
\frac{F(i)_{1}{ }^{t+\Delta t} V_{1}^{t+\Delta t}-F(i)_{1}{ }^{t} V_{1}{ }^{t}}{\Delta t}=-F(i)_{1 u p}^{t} Q_{1}{ }^{t}+F(i)_{2 u p}^{t} Q_{2}{ }^{t}+F(i)_{3 u p}^{t} Q_{3}{ }^{t}
$$

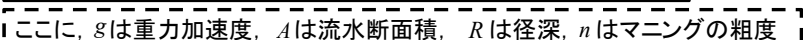
I 係数, $A_{h}$ は水面の面積, $\Delta t$ は計算時間間隔, $\Delta x$ は領域間距離を示し, 添字 はは場所を示す

図-9 解析モデルの支配方程式

表-1 計算条件

導水の時間帯

\begin{tabular}{|c|c|c|c|c|c|c|}
\hline$Q_{\text {in }}$ & 一定導水 & 上げ潮 & 満潮 & 下げ潮 & 干潮 & 運用 \\
\hline 5.6 & CASE A & CASE C-1 & CASE C-2 & CASE C-3 & CASE C-4 & 3時間/1日 \\
\hline 13 & CASE B & CASE D-1 & CASE D-2 & CASE D-3 & CASE D-4 & 3時間/1日 \\
\hline 13 & & CAES E-1 & CASE E-2 & CASE E-3 & CASE E-4 & 3時間/12時間 \\
\hline
\end{tabular}

$\mathrm{Q}_{\text {in }} \mathrm{m} \mathrm{m}^{3} / \mathrm{s}$ 実際の運用: $5.6 \mathrm{~m}^{3} / \mathrm{s}, 5.6 \mathrm{~m}^{3} / \mathrm{s}, 1.8 \mathrm{~m}^{3} / \mathrm{s}$ のポンプにより 1 日3時間 4時 間、1台 $\left(5.6 \mathrm{~m}^{3} / \mathrm{s}\right)$ または2台 $\left(7.4 \mathrm{~m}^{3} / \mathrm{s}\right)$ 使用が多い。

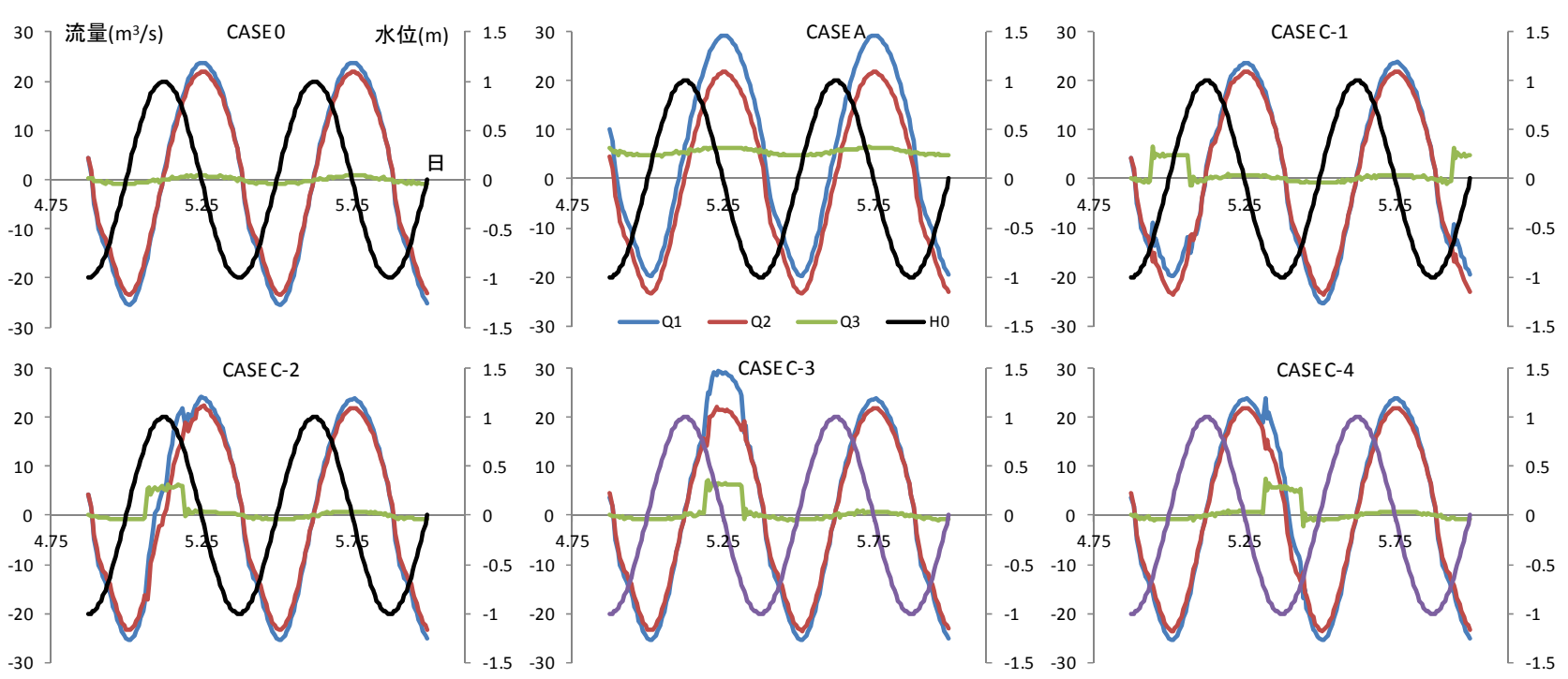

図-10 流量の時間変化（CASE 0,CASE A とCASE C) 


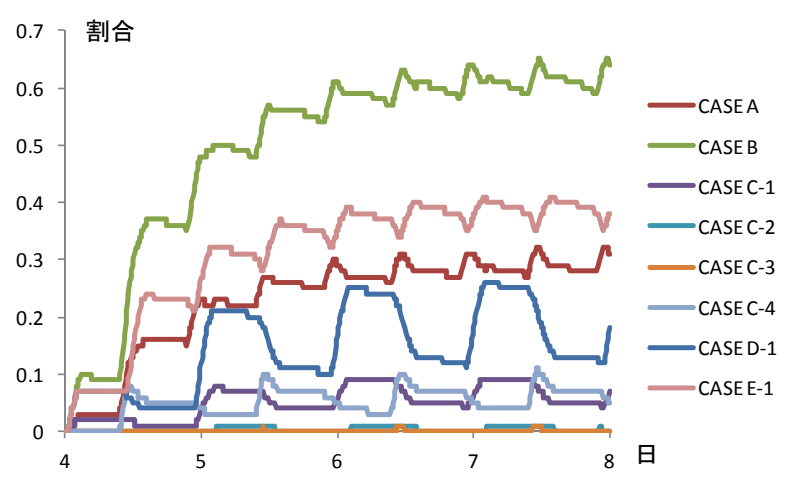

図-11 中川運河の水の上流域に占める割合

$\left(0.3 \mathrm{~m}^{3} / \mathrm{s}\right)$ と城北下水道処理施設からの導水 $\left(0.5 \mathrm{~m}^{3} / \mathrm{s}\right)$ を流入 させた．Fに関する境界条件として，下流のF(1)を1，Qin のF(3)を1 (F(3)in=1), QinupのF(4)を1 (F(4)inup=1)とし, そ の他のFを0とした．初期条件として，干潮の水位および 流量ゼロを与え, 全域に $\mathrm{F}(2)=1, \mathrm{~F}(1)=\mathrm{F}(3)=\mathrm{F}(4)=0$ を与え た. Qinの值は表-1のように変化させた. Qinがゼ口の場 合をCASE 0 とする. 計算条件の中で現実に近い条件は CASE C となる. また, 初期条件の影響を排除寸るためQin をゼロとする流動解析を 4 日間実施し，その後，Qinを変 化させて15日後まで解析を行った.

図-10にCASE 0 とCASE A とCASE Cの流量と水位の時 間変化を示す. CASE Aの場合, CASE 0よりもQ3が約 $5 \mathrm{~m}^{3} / \mathrm{s}$ 増加していることが分かる. CASE C-1〜CASE C-4 は $5.6 \mathrm{~m}^{3} / \mathrm{s} か ゙ 3$ 時間ずつ，上げ潮，満潮，下げ潮，干潮時に 導水しており, その状況に応じたQ1 とQ2の変化が示され ている。 まず，CASEC-4の計算結果から，干潮時の導水 により，Q1では河口へ向かう流れが強まり，Q2では弱ま り流速がゼロの状況も生じている．これは，小潮を想定 した振幅 $0.5 \mathrm{~m}$ の結果も同じであり，図-7に示した観測結 果と同様の傾向が示されている. しかし，実際には松重 閘門から小塩橋までの観測時間約30分間に上流域では停 滞した流れとなっており, 本解析との差も生じている. したがって，今後は細かい領域区分や成層の影響を考慮 した解析を行う必要がある。 また，計算結果から，中川 運河の導水が上流域（H2の水域）に入るには，堀川が上 げ潮となるときに導水することが望ましいと推察され る. 図-11に中流域の導水の割合 (図-9のF(3) $\left.)_{2}\right)$ を示寸. 8 日後〜 15 日後は同様の変動が続いていたので省略して 示している. 本図から, 潮汐の変動に伴う導水のタイミ ングによって，割合が大きく異なることが示され，上げ 潮時 (CASE C,D,E,-1) と干潮時 (CASE C,D,E-4) で中川 運河の水が上流域に輸送されていることが分かる. また, 図-11に示すように，干潮時の導水に関して，導水量 $5.6 \mathrm{~m}^{3} / \mathrm{s}$ の場合（CASE C-1）では $10 \%$ 程度， $13 \mathrm{~m}^{3} / \mathrm{s}$ の場合 (CASE D-1) では25\%程度, 12時間に1回の運用とした場 合（CASE E-1）では40\%程度の割合で，中川運河からの 水が上流域を占める結果となった．実際には，上流域で
全域に同じように混合するわけではなく，また，特に小 潮時に見られる成層の効果などを考慮する必要がある が, 本研究により, 潮汐変動に伴う導水のタイミングの 違いによる移流の特徵が示され，上げ潮の期間に導水す ることで, 中川運河の水を堀川上流域一輸送できること が示された.

\section{5. おわりに}

本研究の成果は以下のとおりである.

1）松重閘門水域部を挟む二つの橋の上から水質観測を 実施し, 堆積しているへドロの水質への影響を検討した. その結果, 潮汐変動に伴う堀川本川の大きな水質変化は 見られなかった．また，観測中に中川運河からの導水が あり, この導水の方が堀川の水質に大きな影響を与えて いることが示された.

2）ADCPを用いて堀川の縦断方向流速分布を明らかにし た．なお，下げ潮時における通常の流れとは異なる導水 時特有の流動特性が示されていた. 中川運河からの導水 はDO值が高い場合があり，この水を堀川上流域へ移流寸 ることで水質改善が図られると考える. しかし，潮汐変 動に伴う導水のタイミングによっては, 中川運河の水が 上流域に輸送されない可能性も示された.

3) 対象とする水域を簡単なモデルで表現して, 導水の上 流域一の輸送を数值解析的に検討した. その結果, 通常 の導水の運用を上げ潮時に行うことで，最大で，上流域 の10\%の水が中川運河からの水となることが示された.

また, 潮汐に関する導水のタイミングにより, 上流域に 輸送される導水の影響が大きく異なる結果となった. 既 存の施設を活用した現実的な方法として, 導水量を $13 \mathrm{~m}^{3} / \mathrm{s}$ に増やした場合と 2 回/ 1 日に増やした場合では，それぞ れ $25 \%$ ，40\%と值の改善がみられた。

\section{参考文献}

1)武田誠, 原田守博, 富永晃宏他 : 堀川における浮遊ゴ ミの移動特性に関する研究, 水工学論文集第52巻, pp.1111-1116, 2008.

2)武田誠, レグミウゲンダ, 松尾直規 : 堀川における浮 遊物の移動特性とへドロの体積状況との関係, 水工学論 文集54巻, pp.1189-1194， 2010.

3)武田誠，松尾直規 : 堀川の流れと水質に関する現地調 查, 水工学論文集第51巻, pp.1135-1140, 2007.

4)武田誠, 日置梓, 遠山智, 松尾直規 : 冬季の堀川の水 質変化に関する現地観測と数值解析, 環境工学論文集第 43巻, pp.483-491, 2006.

5)富永晃宏, 佐々木高士, 郭緯 : 堀川の潮汐変動に伴う 流量特性と河岸凹部の流孔構造の現地観測, 水工学論文 集52巻, pp.781-786, 2008.

(2013.9.30受付) 